\title{
Oralidade, leitura e escrita: estratégias e aspectos cognitivos na práxis pedagógica
}

\author{
Valquiria Claudete Machado Borba (UNEB) \\ https://orcid.org/0000-0002-1855-439X
}

\section{Resumo:}

Este artigo tem por objetivo trazer reflexões baseadas em três propostas elaboradas por meio de sequências didáticas de mestrandas (hoje mestras) orientadas por nós no Mestrado Profissional em Letras - PROFLETRAS, no Departamento de Ciências Humanas do Campus V da Universidade do Estado da Bahia - UNEB, que auxiliaram no desenvolvimento da oralidade, da leitura e da escrita de seus alunos. A partir da elaboração e aplicação das sequências didáticas, tendo como base uma perspectiva cognitiva, pontuamos fatores envolvidos na aprendizagem que foram observados e que são importantes para uma práxis mais significativa e eficaz.

Palavras-chave: Oralidade; Leitura; Escrita; Cognição; Estratégias.

\section{Abstract:}

\section{Orality, reading and writing: strategies and cognitive aspects in pedagogical praxis}

This paper aims to bring reflections based on three proposals elaborated through didactic sequences of master's students (today masters) guided by us in the Professional Master's in Letters - PROFLETRAS, in the Department of Human Sciences at Campus V of the State University of Bahia - UNEB who helped in the development of their students' orality, reading and writing. From the elaboration and application of the didactic sequences, based on a cognitive perspective, we point out factors involved in learning that were observed and that are important for a more meaningful and effective praxis.. Keywords: Orality; Reading; Writing; Cognition; Strategies.

\footnotetext{
* Mestre em Letras (PUCRS - 2005) e doutora em Letras e Linguística (UFAL - 2009). Líder do Grupo de Estudos em Educação e Linguagem - GEEL (Diretório Nacional CNPq). Atualmente é professora adjunta da Universidade do Estado da Bahia - UNEB no Departamento de Educação - Campus I e vice-coordenadora do Mestrado Profissional em Letras (PROFLETRAS - Campus de Santo Antônio de Jesus). Tem experiência na área de Letras e Pedagogia, com ênfase em Linguística Aplicada à Educação. Áreas de interesse: psicolinguística, leitura, escritura, alfabetização, processos cognitivos, conexionismo, aquisição da linguagem, educação a distância, EJA, formação de professores. Lattes: http://lattes.cnpq.br/3037018518459819. E-mail: valmborba@hotmail.com
} 


\section{Introdução}

Estamos no século XXI, há mais de 20 anos do lançamento dos Parâmetros Curriculares Nacionais - PCN - (Brasil, 1998), adentrando em um novo momento da educação com a Base Nacional Comum Curricular - BNCC (Brasil, 2017), e seguimos enfrentando os mesmos problemas na educação brasileira: uma parcela significativa de nossos estudantes termina o ensino fundamental e médio sem um domínio efetivo das práticas sociais da oralidade, leitura e escrita.

Mas o que têm feito as universidades formadoras de professores para mudar essa realidade? A complexidade envolvida no ato de educar envolve vários fatores internos e externos, e cada região apresenta demandas diferentes, cada escola apresenta distintas questões. E nesse caminho, a universidade e seus pesquisadores vêm refletindo sobre os diversos ambientes escolares, suas possibilidades, suas metodologias, seus alunos etc.

Nesta direção, trazemos reflexões baseadas em propostas elaboradas por meio de sequências didáticas de mestrandas (hoje mestras) orientadas por nós no Mestrado Profissional em Letras - PROFLETRAS ${ }^{1}$,

1 O Programa de Mestrado Profissional em Letras - PROFLETRAS - é oferecido em rede Nacional, é um Curso semipresencial que conta com a participação de Instituições de Ensino Superior, no contexto da Universidade Aberta do Brasil (UAB), tendo sua sede na Universidade Federal do Rio Grande do Norte. 0 mestrado reúne 42 universidades públicas das cinco regiões brasileiras, totalizando 49 unidades, tendo em vista que há quatro universidades que oferecem mais de uma unidade. O PROFLETRAS visa à capacitação de professores de Língua Portuguesa para o exercício da docência no Ensino Fundamental, com o intuito de contribuir para a melhoria da qualidade do ensino no País. (Fonte: Disponível em: <http:// no Departamento de Ciências Humanas do Campus V da Universidade do Estado da Bahia - UNEB, que auxiliaram no desenvolvimento da oralidade, leitura e escrita de seus alunos. Mas antes de adentrar nas propostas desenvolvidas, discutiremos um pouco sobre aprendizagem e cognição à luz do que a neurociência vem mostrando em termos de fatores envolvidos na aprendizagem, conhecimentos fundamentais para pensar a educação.

\section{Cognição e aprendizagem}

Aprender é, em termos neurocientíficos, reforçar sinapses, ou seja, a aprendizagem ocorre quando

Há uma modificação da estrutura neural microanatômica no ponto onde a informação é armazenada e reinstanciada com o objetivo de gerar comportamento. Nesse sentido, o desenvolvimento da linguagem no ser humano não difere da aprendizagem de qualquer outra forma de conhecimento - fisiolgicamente, traduz-se por uma alteração no substrato natural, decorrente da exposição do organismo ao meio. (CHIELE, 1998, p. 59).

Conforme Borba (2013, p. 37-38),

0 aprendizado acontece através do reforço das sinapses, que é uma associação entre dois neurônios, sendo que um ou ambos podem ser responsáveis pelo aumento da eficiência da sinapse. Essa associação se dá através de reações químicas no espaço entre os pontos onde um axônio encontra um dentrito, sendo essas reações responsáveis pelo aprendizado.

www.profletras.ufrn.br/organizacao/apresentacao\#.VztJfvkrLIU> - Acesso em: 19 março 21). 
Figura 1 - A sinapse

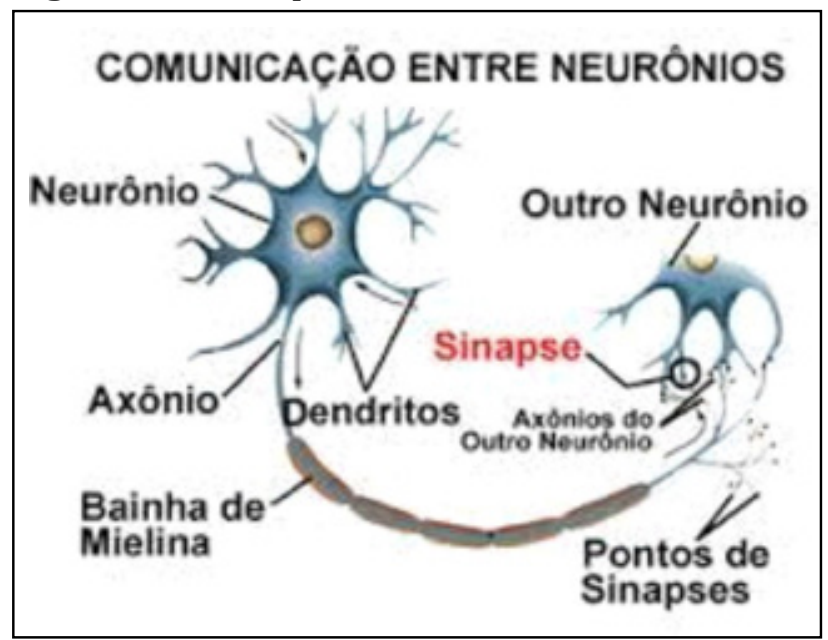

Fonte: Disponível em: <https://bit.ly/2BYsu7N> Acesso em: 30 ago 2016. (Ver BORBA, 2018, p. 236).

Para que haja essa modificação da estrutura neural microanatômica, ou seja, para que haja reações químicas favoráveis e suficientes ao aprendizado, vários fatores estão envolvidos, pois aprender é um processo biológico, complexo, multirreferencial, que acontece ao longo da vida, envolvendo do genético ao meio ambiente que nos cerca. Assim, compreender quais são os processos envolvidos na aprendizagem é fundamental para que os professores vejam os seus alunos reais, como são, qual o contexto social deles, seus interesses, desejos, objetivos, e em que condições estão expostos ao conhecimento, quais são suas condições físicas, psicológicas, estruturais, biológicas, sociais etc., de forma a elaborar o seu planejamento levando em conta as necessidades dos alunos para que se tornem cidadãos plenos, que terão desenvolvido as habilidades e competências necessárias às demandas sociais, à interação nos mais variados ambientes. Contudo, para Borba (2018, p. 233), “apesar dos avanços sobre a compreensão de como o cérebro aprende, que estímulos biológicos, cognitivos, sociais, interacionais e ambientais favorecem o aprendizado, pouco se discute nas licenciaturas a respeito desses aspectos." Infelizmente, o cérebro ainda é um mistério para a maioria dos professores, muitas vezes, visto como um aspecto a ser estudado em biologia apenas, como se nós, seres humanos, não fôssemos constituídos biologicamente, e, portanto, a biologia devendo ser parte de todos os estudos que envolvam seres humanos. Borba (2018, p.236236) diz que

É preciso disseminar entre os educadores os estudos atuais sobre cognição e ensino -aprendizagem, pois esses estudos trazem contribuições importantes para a práxis em sala de aula, ora confirmando a prática, muitas vezes, intuitiva dos professores, ora questionando-a, ora apresentando sugestões a partir da compreensão do que ocorre no espaço da sala de aula, levando em conta o nicho cognitivo que este representa.

Segundo a autora,

aprendemos a partir das nossas experiências, da forma como percebemos o mundo, como interagimos. Na prática da sala de aula, significa que o aprender vai depender de muitos fatores como o ambiente físico, a interação entre professor-aluno, aluno-aluno, escola-família, etc., os recursos utilizados, a metodologia, a prática, ou seja, o tempo de experiência, a frequência de exposição a determinado assunto, o conhecimento prévio do aluno, o conhecimento prévio partilhado, o objetivo, o desejo, a motivação, a atenção, etc. Quando pensamos em como se aprende, são tantos os fatores envolvidos, que, de certa forma, por mais que busquemos pensar sobre metodologias e estratégias, estaremos sempre pensando em possibilidades, nada mais que isso, contudo, quanto mais possibilidades, mais estratégias, maior é chance de se alcançar sucesso no ensino-aprendizagem. Assim, é muito importante pensar, refletir sobre tudo que pode promover o aprendizado, que pode estabelecer e reforçar sinapses, e, nessa direção, quanto mais entendermos sobre cognição, mais chances temos de (re)pensar a nossa sala de aula, pensar em metodologias e estratégias a partir do sujeito cognoscente real, singular com 
o qual interagimos, compreendendo o contexto em que estamos e atuando sobre ele de forma a favorecer a aprendizagem da melhor forma possível. (BORBA, 2018, p. 238)
Em seu artigo Cognição e ensino-aprendizagem: da teoria à prática, Borba (2018, p. 239) apresenta um quadro sobre os fatores envolvidos na aprendizagem:

Quadro 1 - Fatores envolvidos na aprendizagem

\begin{tabular}{|c|c|c|c|c|c|}
\hline Ambientais & Interacionais & Biológicos & Cognitivos & Subjetivos & $\begin{array}{l}\text { Tempo de } \\
\text { experiência } \\
\text { prática }\end{array}$ \\
\hline 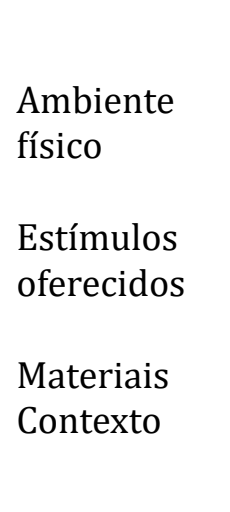 & $\begin{array}{l}\text { Contexto } \\
\text { Relação } \\
\text { interpessoal } \\
\text { Emoção/Afeto } \\
\text { Cultura } \\
\text { Metodologia }\end{array}$ & $\begin{array}{l}\begin{array}{l}\text { Aspectos } \\
\text { genéticos }\end{array} \\
\text { Organismo } \\
\text { saudável } \\
\text { Estado de } \\
\text { vigília }\end{array}$ & $\begin{array}{l}\text { Conhecimento } \\
\text { prévio } \\
\text { Habilidades } \\
\text { cognitivas } \\
\text { Habilidades } \\
\text { metacognitivas } \\
\text { Atenção }\end{array}$ & $\begin{array}{l}\text { Objetivo } \\
\text { Motivação } \\
\text { Desejo } \\
\text { Interesse } \\
\text { Relevância } \\
\text { Experiência }\end{array}$ & $\begin{array}{l}\text { Frequência } \\
\text { Regularidade }\end{array}$ \\
\hline
\end{tabular}

Fonte: Borba (2018, p. 239).

Para Borba (2018, p. 238-239),

Aprender, nessa perspectiva, depende de vários fatores: ambientais, interacionais, biológicos (BORBA, 2013), cognitivos, subjetivos e de experiência. Fatores estes tão variados e complexos e que intervêm na formação/ reforço das sinapses, no aprendizado. Quanto mais soubermos sobre esses fatores, melhores condições teremos de compreender o nosso nicho cognitivo que é a sala de aula, buscando estratégias de ensino-aprendizagem que vão ao encontro do nosso aluno, que despertem nele o interesse, atraiam a sua atenção, permitam, assim, práticas significativas.

Tendo em vista os fatores apresentados por Borba (2018), buscaremos verificá-lo nas três sequências didáticas a seguir.

\section{Oralidade: uma proposta de sequência didática}

A oralidade foi tema da dissertação Argumentação na oralidade: uma proposta de en- sino a partir dos gêneros diálogo argumentativo e debate (2017) da nossa orientanda Terêsa Cristina Cardoso de Souza Viana, que apresenta uma sequência didática aplicada em 24 horas/aulas com alunos que cursavam o nono ano do Ensino Fundamental II em um colégio público da cidade de Cruz das Almas, Bahia. Teresa queria muito desenvolver uma sequência didática que desenvolvesse a argumentação na oralidade, pois, para a mestra,

o que vivenciamos na escola no nível fundamental é um ensino que prioriza a escrita, com prejuízo da oralidade, esta fica relegada a um plano inferior em relação àquela. Esse fato se intensifica ainda mais, no que se refere ao ensino da argumentação oral, pois mesmo a argumentação escrita, apesar de mais enfocada que a oral, ainda assim se apresenta deficitária nesse nível de ensino, no qual as intenções dos docentes recaem sobre os gêneros, em que predominam as sequências narrativas e descritivas. Isso resulta 
numa falta de familiaridade dos alunos, que cursam o nível fundamental, com os gêneros discursivos orais em situações formais. Essa é uma realidade presenciada por nós ao longo de nossa prática no ensino básico, e nos impulsionou para a realização desta proposta de intervenção, na expectativa de que a mesma venha subsidiar a construção da aprendizagem, como também disseminar práticas educativas que corroborem para a efetivação de um ensino de língua materna mais substancial, principalmente, no que tange à modalidade oral dessa língua, sem, contudo, desprezar a escrita. (VIANA, 2017, p. 17).

Para Ávila, Nascimento e Gois (2012, p.37 apud VIANA, 2017, p. 23), “cabe ao pro- fessor de língua materna a responsabilidade de contribuir para que os educandos desenvolvam também as competências linguístico -interacionais que estão ligadas às práticas sociais no âmbito da oralidade".

Viana (2017) elaborou uma sequência didática considerando o conhecimento prévio dos alunos, temas de interesse para os debates que seriam realizados por meio do diálogo argumentativo e do debate. Para termos uma ideia, vejamos o módulo 1 de atividades de Viana, aplicado após uma atividade diagnóstica de debate acerca do bullying na escola para detecção dos conhecimentos prévios da turma:

Quadro 2 - Procedimentos do Módulo 1

\begin{tabular}{|c|c|c|c|c|}
\hline \multicolumn{5}{|c|}{ MÓDULO 1 (08horas/aulas) } \\
\hline $\begin{array}{c}\text { Oficinas } \\
\text { (04) }\end{array}$ & Primeira & Segunda & Terceira & Quarta \\
\hline Tema & \multicolumn{3}{|c|}{ A prática do bullying na escola } & $\begin{array}{l}\text { A terceira } \\
\text { idade }\end{array}$ \\
\hline Tempo & $\begin{array}{l}\text { 02horas/ } \\
\text { aulas }\end{array}$ & $\begin{array}{l}\text { 02horas/ } \\
\text { aulas }\end{array}$ & $\begin{array}{l}\text { 02horas/ } \\
\text { aulas }\end{array}$ & $\begin{array}{l}\text { 02horas/ } \\
\text { aulas }\end{array}$ \\
\hline Conteúdo & $\begin{array}{l}\text { Argumentação } \\
\text { no diálogo }\end{array}$ & $\begin{array}{l}\text { O diálogo } \\
\text { argumentativo. } \\
\text { (Noções) }\end{array}$ & $\begin{array}{l}\text { Sistematização } \\
\text { do diálogo } \\
\text { argumentativo. }\end{array}$ & $\begin{array}{l}\text { O gênero } \\
\text { debate e suas } \\
\text { especificidades }\end{array}$ \\
\hline Objetivos & $\begin{array}{l}\text { Socialização do } \\
\text { diálogo da fase } \\
\text { diagnóstica; } \\
\text { Observar } \\
\text { e analisar } \\
\text { desempenho no } \\
\text { diálogo; } \\
\text { Perceber a } \\
\text { utilização de } \\
\text { opiniões. }\end{array}$ & $\begin{array}{l}\text { Responder } \\
\text { questionário; } \\
\text { Ler e compreender } \\
\text { a transcrição do } \\
\text { diálogo; } \\
\text { Localizar opiniões } \\
\text { consistentes no texto } \\
\text { transcrito; } \\
\text { Identificar na } \\
\text { transcrição do } \\
\text { diálogo as opiniões } \\
\text { semelhantes e as } \\
\text { divergentes. }\end{array}$ & $\begin{array}{l}\text { Observar a prática } \\
\text { do diálogo } \\
\text { argumentativo } \\
\text { numa instância } \\
\text { formal; } \\
\text { Compreender as } \\
\text { especificidades } \\
\text { do diálogo } \\
\text { argumentativo; } \\
\text { Diferenciar os tipos } \\
\text { de diálogos. }\end{array}$ & $\begin{array}{l}\text { Identificar o } \\
\text { gênero debate; } \\
\text { Entender a } \\
\text { estrutura } \\
\text { composicional do } \\
\text { gênero debate. }\end{array}$ \\
\hline
\end{tabular}




\begin{tabular}{|c|c|c|c|c|}
\hline $\begin{array}{l}\text { Procedi- } \\
\text { mentos }\end{array}$ & $\begin{array}{l}\text { Mostra } \\
\text { de vídeos } \\
\text { (sociali- } \\
\text { zação da } \\
\text { filmagem } \\
\text { do diagnós- } \\
\text { tico); Ob- } \\
\text { servação do } \\
\text { desempe- } \\
\text { nho e par- } \\
\text { ticipação } \\
\text { no diálogo; } \\
\text { Localização } \\
\text { de opiniões } \\
\text { utilizadas. }\end{array}$ & $\begin{array}{l}\text { Leitura e } \\
\text { compreensão } \\
\text { da transcrição } \\
\text { do diálogo } \\
\text { argumentativo; } \\
\text { Localização } \\
\text { de opiniões na } \\
\text { transcrição; } \\
\text { Identificação } \\
\text { das opiniões } \\
\text { semelhantes e } \\
\text { divergentes. }\end{array}$ & $\begin{array}{l}\text { Aplicação de } \\
\text { questionário; } \\
\text { Mostra de } \\
\text { vídeo contendo } \\
\text { um diálogo } \\
\text { argumentativo } \\
\text { em um programa } \\
\text { de televisão; } \\
\text { Exposição de } \\
\text { conteúdo com } \\
\text { auxílio de slides. }\end{array}$ & $\begin{array}{l}\text { Mostra } \\
\text { de vídeo } \\
\text { contendo } \\
\text { debate entre } \\
\text { alunos; } \\
\text { Exposição e } \\
\text { discussão de } \\
\text { conteúdo. }\end{array}$ \\
\hline Recursos & $\begin{array}{l}\text { Caixa } \\
\text { acústica, } \\
\text { data show, } \\
\text { notebook, } \\
\text { pendrive. }\end{array}$ & $\begin{array}{l}\text { Data show, } \\
\text { notebook, textos } \\
\text { xerocopiados. }\end{array}$ & $\begin{array}{l}\text { Caixa acústica, } \\
\text { data show, } \\
\text { notebook, slides, } \\
\text { pendrive. }\end{array}$ & $\begin{array}{l}\text { Caixa acústica, } \\
\text { data show, } \\
\text { notebook, } \\
\text { slides, Cópias } \\
\text { (apostila). }\end{array}$ \\
\hline
\end{tabular}

Fonte: Viana (2017, p. 68)

Além deste módulo, houve mais um com 12 horas aula. Antes dos dois módulos de desenvolvimento da argumentação na oralidade, como dito antes, houve uma atividade diagnóstica de 02 horas/aulas, que serviu como base para a professora verificar os conhecimentos dos alunos em termos de argumentação. E, no final dos módulos, houve uma produção final:

Nesta etapa, com carga horária de 02 horas/ aulas, aconteceram os debates (produção final), a ordem em que aconteceu foi mediante sorteio entre as equipes. Também acer- tamos previamente que as equipes que não estivessem debatendo no momento, fariam parte do auditório. No dia do debate coube a cada equipe o tempo estabelecido para realização de seu debate, decidimos dessa forma porque havíamos estipulado o tempo máximo de 100 minutos (02 horas/aula), para a culminância de nossa proposta, em equivalência à produção inicial. (VIANA, 2017, p. 75).

Vejamos abaixo a organização dos debates para a produção final organizados por Viana (2017, p. 75):

Tabela 1 - Organização dos debates e especificação dos participantes.

\begin{tabular}{|c|c|c|c|c|}
\hline & & & EQUIPE & \\
\hline \multirow[t]{2}{*}{ DEBATE } & TEMA & & \multicolumn{2}{|c|}{ Debatedores } \\
\hline & & Moderador & A favor & Contra \\
\hline 01 & A legalização do aborto & A11 & $\begin{array}{l}\text { A } 10 \\
\text { A } 12 \\
\text { A20 }\end{array}$ & $\begin{array}{l}\text { A } 4 \\
\text { A } 18 \\
\text { A19 }\end{array}$ \\
\hline 02 & $\begin{array}{l}\text { A implantação da pena de } \\
\text { morte }\end{array}$ & A1 & $\begin{array}{l}\text { A } 7 \\
\text { A } 9 \\
\text { A } 23\end{array}$ & $\begin{array}{l}\text { A } 6 \\
\text { A } 14 \\
\text { A17 }\end{array}$ \\
\hline
\end{tabular}




\begin{tabular}{c|l|c|c|c}
\hline 03 & A reforma do ensino médio & A3 & A2 & A15 \\
A24
\end{tabular}

Fonte: Viana (2017, p. 75).

As atividades propostas por Viana para o desenvolvimento da oralidade foram pensadas por meio de uma sequência didática que levasse os alunos a desenvolverem-se em termos de argumentação oral. Para isso, a professora procurou antes verificar seus conhecimentos prévios, selecionou temas, vídeos e textos que fossem interessantes para os alunos e permitissem debates.

A conclusão de Viana (2017, p. 119-120) sobre o desenvolvimento da sequência didática foi:

No que tange as nossas categorias de análise, as operações de formulação, retomada, reformulação e refutação de argumentos; os operadores argumentativos e os argumentos, a partir de nossa análise, percebemos que na fase diagnóstica os alunos utilizaram argumentos, operadores argumentativos e realizaram algumas operações de refutação, de retomada e de reformulação. Contudo, essas ações ainda foram insatisfatórias, pois, constatamos que os alunos careciam de um maior conhecimento linguístico e habilidades para sua realização. Visando suprir essas deficiências ao longo de nossa sequência realizamos as diversas atividades discutidas no capítulo metodológico até chegar a nossa produção final com a qual observamos um desenvolvimento maior das operações necessárias à argumentação, como a formulação de argumentos consistentes, a retomada, a reformulação e a refutação, atitude necessária à argumentação dialogal, conforme Plantin (2008) e Leitão (2011). Além disso, houve um crescimento linguístico no que concerne aos tipos de operadores e argumentos utilizados na produção final, em comparação a inicial, posto que observa- mos uma utilização mais adequada desses operadores argumentativos, principalmente os que foram utilizados em argumentos de contradição, de conclusão, de explicação e de justificação. Esse uso contribuiu com uma formulação mais precisa dos pontos de vista enunciados. Também detectamos uma maior variação quanto aos operadores usados, pois percebemos 29 tipos de operadores na produção inicial em 94 turnos, contra 50 tipos encontrados no discurso dos debatedores na produção final, os debates, num total de 54 turnos. No que se refere à construção de argumentos, na produção inicial, encontramos 12 tipos e na produção final, constatamos 16 tipos. Dentre esses argumentos, dez apresentaram um percentual maior de utilização na produção final. Vale ressaltar também que o uso desses argumentos foi muito mais consistente que o da primeira etapa, pois houve um ajustamento maior entre o operador e o argumento direcionando para conclusões plausíveis, de acordo com a intenção discursiva dos alunos.

Como podemos perceber, o trabalho com a língua oral é fundamental para o desenvolvimento de competências e habilidades nesta modalidade. Embora ainda pouco presente nas escolas, há profissionais engajados em mudar isso, colocando a modalidade oral em um patamar de reconhecimento da sua importância na sociedade e, portanto, na escola.

Vejamos agora a proposta desenvolvida por nossa orientanda Erenice Rocha dos Santos, que trabalhou com uma sequência didática que desenvolveu atividades utilizando o conhecimento prévio como estratégia de leitura. 


\section{Leitura e conhecimento prévio: uma relação intrínseca}

0 trabalho com a leitura deve ser constante, pois ler depende de inúmeros fatores, entre eles o conhecimento prévio. Erenice Rocha dos Santos desenvolveu sua dissertação de mestrado no PROFLETRAS abordando o conhecimento prévio enquanto estratégia de leitura: Conhecimento prévio e compreensão leitora: uma proposta pedagógica (2015):

0 presente trabalho surgiu das inquietações, acentuadas ao longo da nossa atividade profissional, com relação ao desenvolvimento da competência leitora dos alunos, especificamente as turmas do $7^{\circ}$ e $8^{\circ}$ ano do Ensino Fundamental, da escola onde lecionamos. 0 desempenho dos alunos nas atividades de leitura tem sido uma preocupação constante, precisamos buscar caminhos para amenizar as lacunas existentes e fazer com que os alunos se sintam atraídos pela leitura e consigam atribuir sentido ao que leem.

Os alunos, na sua maioria, sentem muita dificuldade em compreender o que leem, não sabem atribuir sentido ao texto, não sabem quais caminhos percorrer para chegar à compreensão, e, talvez, por isso resistam tanto à leitura, dizem que não gostam de ler, se recusam a trabalhar com o texto em sala de aula. (SANTOS, 2015, p. 14)

\section{Para Santos (2015, p. 15),}

O desafio do professor, então, não é ensinar o aluno a ler, e sim, tornar o aprendizado da leitura algo possível, acessível aos alunos (SMITH, 1999). Para levar o aluno a se tornar um leitor autônomo, capaz de compreender qualquer texto, é preciso o ensino de estratégias que o leve à proficiência em leitura, ou seja, compreender, interpretar um texto em qualquer situação.

Assim, Santos (2015) desenvolveu uma sequência didática trabalhando atividades a partir da ativação do conhecimento prévio. Conforme a pesquisadora,
Kleiman (2013) apresenta três tipos de conhecimentos prévios, sendo eles conhecimento linguístico, textual e de mundo. Para ela, esses conhecimentos são indispensáveis para que o leitor construa o sentido do texto. 0 primeiro refere-se às palavras, aos sintagmas e às estruturas frasais. 0 segundo está relacionado aos tipos e estruturas textuais e o terceiro está relacionado ao conhecimento adquirido ao longo da vida, o qual colabora nas inferências e compreensão de pressupostos, fazendo com que o leitor perceba as pistas deixadas pelo autor, preenchendo as lacunas e tornando a leitura significativa. (SANTOS, 2015, p. 16).

\section{Para Santos (2015, p. 16),}

A ativação do conhecimento prévio do leitor é importante na compreensão leitora, pois possibilita ao aluno tomar consciência da necessidade de fazer da leitura uma atividade de interação entre o autor-texto-leitor (ELIAS; KOCH, 2013), engajamento e uso do conhecimento. É importante entender como o conhecimento adquirido determina, durante a leitura, as inferências que o leitor poderá realizar através dos elementos textuais. O conhecimento prévio seja ele linguístico, textual ou de mundo, deve ser ativado durante a leitura para poder alcançar compreensão.

Buscando desenvolver uma sequência didática para o desenvolvimento da competência leitora, trazendo o conhecimento prévio como uma estratégia, Santos trabalhou com uma turma de

[..] oitavo ano do Ensino Fundamental, de uma escola localizada na Zona Urbana de Amargosa - BA, em um bairro periférico da cidade. $\mathrm{O}$ quadro discente da escola é composto por adolescentes oriundos da zona rural, meninos e meninas que estudavam em escolas de primeiro ao quinto ano, localizadas nas comunidades rurais, que depois de concluírem o quinto ano ( $4^{\underline{a}}$ série) do Ensino Fundamental, são transferidos para as escolas da zona urbana. (SANTOS, 2015, p. 16). 
Como todos os estudos orientados por nós no PROFLETRAS, Santos também aplicou uma atividade diagnóstica:

A proposta de intervenção pedagógica foi pensada a partir da atividade diagnóstica, que revelou um baixo desempenho com relação à compreensão leitora dos nossos alunos. Esse resultado nos leva a refletir sobre nossa escola e sobre as atividades de leitura. Apesar de termos uma biblioteca na escola, esta não é bem frequentada, muitos alunos não se sentem atraídos pelos livros. 0 que ouvimos de muitos é que a aula de leitura é chata, e só vão à biblioteca quando a professora exige que leiam determinada literatura, sob a pressão de obter uma nota.
Através dessa atividade, vimos que vários alunos apresentam dificuldades para leitura. Muitos ainda não sabem ativar seus conhecimentos previamente armazenados a favor da compreensão, ou não têm conhecimentos prévios suficientes para compreender os textos, além de não demonstrarem muito gosto pela leitura, muitos alunos sentem dificuldades na hora de ler e compreender um texto. (SANTOS, 2015, p. 17).

Tendo em vista o exposto, Santos partiu dos níveis de conhecimentos prévios para elaborar uma sequência didática para o desenvolvimento da compreensão leitora:

Quadro 3 - Níveis de conhecimentos prévios

\begin{tabular}{|l|l|l|}
\hline \multicolumn{3}{|c|}{ Conhecimentos } \\
\hline \multicolumn{1}{|c|}{ Linguísticos: } & \multicolumn{1}{|c|}{ Textuais: } & \multicolumn{1}{c|}{ Enciclopédico: } \\
\hline $\begin{array}{l}\text { Os conhecimentos } \\
\text { léxicos e semânticos - as } \\
\text { palavras que compõem } \\
\text { a língua portuguesa e a } \\
\text { significação dos vocábulos - } \\
\text { vocabulário; }\end{array}$ & $\bullet$ & Gênero textual; \\
$\begin{array}{l}\text { Morfológicos e Sintáticos } \\
\text { - as classes gramaticais e a } \\
\text { função das palavras dentro } \\
\text { do contexto }\end{array}$ & $\bullet \begin{array}{l}\text { Organização da } \\
\text { narrativa; }\end{array}$ & $\bullet \begin{array}{l}\text { Conhecimento de mundo; } \\
\text { necessários para ententonder o } \\
\text { texto. }\end{array}$ \\
\hline
\end{tabular}

Fonte: SANTOS (2015, p. 45).

Ao pensar nos textos que escolheria, Santos procurava pensar no contexto social de seus alunos e em como ampliar sua visão de mundo. Assim, elaborou uma sequência de cinco aulas. Como ilustração, trazemos a aula 3, que trabalhou com o conto "Negrinha" de Monteiro Lobato.

\section{3a AULA: "Negrinha"}

a) Apresentação da capa do livro que contém o conto;

b) Questionário oral para fomentar a análise:

- Analise a capa do livro. 0 que você pode observar? Quais elementos estão presentes? O que mais lhe chama a atenção? 
- Observe a palavra negrinha. Quais são os sentidos contidos nessa palavra? Exemplos de como essa palavra é usada no cotidiano.

c) Levantar hipótese- previsões sobre o texto a partir de imagens

Pediremos que eles observem as imagens e façam previsões sobre o conto que iremos ler:

- Analisem as imagens. 0 que vocês conseguem ver?

- Qual época histórica do nosso país é retratado nas imagens?

- Tomando como ponto de partida a capa do livro com todos esses elementos e o título do conto; sobre o que vocês imaginam que ele irá tratar?

d) Apresentação do autor Monteiro Lobato

e) Leitura dirigida

f) Questionário de compreensão leitora.

\section{Atividade de compreensão leitora:}

\section{Mobilização dos conhecimentos prévios linguísticos:}

1. Faça um levantamento das palavras e expressões que caracterizam a Negrinha e a personagem dona Inácia no conto e informe a que classe de palavras pertencem.

2. Como já foi evidenciado, o texto contém expressões irônicas. Observe os trechos a seguir e destaque a ironia em cada um e explique:

a) "Que idéia faria de si essa criança que nunca ouvira uma palavra de carinho? Pestinha, diabo, coruja, barata descascada, bruxa, pata-choca, pinto gorado, mosca-morta, sujeira, bisca, trapo, cachorrinha, coisa-ruim, lixo - não tinha conta o número de apelidos com que a mimoseavam"

b) "[...] e qualquer coisinha: a polícia! "Qualquer coisinha”: uma mucama assada ao forno porque se engraçou dela o senhor; uma novena de relho porque disse: "Como é ruim, a sinhá!"..."

3. Observe cada trecho a seguir e busque o significado das palavras destacadas assinalando a alternativa correta.

a) Dona Inácia estava azeda, necessitadíssima de derivativos. 
( ) Remédio, calmante;

( ) Ocupação, divertimento para distrair ou para fugir à realidade;

( ) Descanso, férias.

b) 013 de Maio tirou-lhe das mãos o azorrague,

( ) Chicote ( ) Anel de princesa ( ) Autoridade de patrão

"[...] uma mucama assada ao forno porque se engraçou dela o senhor; [...]"
() Criança escrava
( ) Escrava que ajudava nos serviços da casa

( ) Mulher que já foi escrava e agora é livre

4. Observe a frase: “Brincara!..”. Composta, por apenas uma palavra, verbo brincar no pretérito mais-que-perfeito do Indicativo e com reticências no final a frase fica carregada de significações. Por que, em sua opinião, o autor a compôs assim? Com o uso de pretéritos diferentes, como por exemplo, os verbos: Brincou!... (Pretérito perfeito do indicativo) e Brincava!... (Pretérito imperfeito do indicativo) Ocorreria mudança de sentido? Caso positivo, informe qual.

\section{Mobilização dos conhecimentos prévios textuais}

5. O conto "Negrinha" é narrativa em terceira pessoa, impregnada de uma carga emocional muito forte. Assim podemos afirmar que o tipo de narrador é:
a) Narrador observador
b) Narrador personagem

6) Aponte uma passagem do texto que comprove a sua resposta na questão anterior.

7) Para que essa história seja dotada de sentido, ela precisa atender a critérios específicos no que se refere aos seus elementos constitutivos. Identifiquem no conto "Negrinha" alguns desses elementos:
a) Personagens principais e secundários
b) Tempo cronológico e psicológico:
c) Espaço:
d) Enredo: 


\section{Mobilização dos conhecimentos prévios enciclopédicos}

8) A época que se passa a história não é exatamente citada no conto, porém é possível inferir através de elementos do texto. De acordo com o texto, informe a época e localize uma passagem que comprove sua resposta.

9) 0 conto foi publicado em 1920 e o autor Monteiro Lobato denuncia uma situação social vivida no Brasil naquela época. Que denúncia é essa?

\section{( ) A situação de pobreza dos brasileiros}

() A desigualdade racial, o trabalho escravo apesar de que quando foi publicado o conto não se vivia mais em um país escravocrata;

( ) A denúncia que faz é sobre a exploração do trabalho infantil, já que no conto a menina fazia crochê.

10) Releia o trecho a seguir: "O 13 de Maio tirou-lhe das mãos o azorrague, mas não lhe tirou da alma a gana. Conservava Negrinha em casa como remédio para os frenesis. Inocente derivativo". Por que o narrador se remete ao 13 de maio? Que ligação tem essa data com Negrinha e sua condição diante de dona Inácia? 0 que essa data deveria ter mudado nas atitudes de dona Inácia?

Fonte: SANTOS (2015, p. 50-53).

Para Santos (2015, p.59-60),

Cada aula foi um novo aprendizado, percebemos, muitas vezes, alguns alunos desmotivados, sem muito interesse para participar da atividade. Porém, quando iniciávamos a aula, eles iam se integrando. A primeira aula de intervenção foi algo novo para eles, falamos sobre ativar os conhecimentos pré-adquiridos e para eles foi uma grata surpresa saber que traziam algo consigo e que o que eles já sabiam poderia ser usado para compreender algo novo.

Ao iniciarmos cada aula, fazíamos levantamento de hipóteses, ativação dos conhecimentos prévios, e sempre depois da leitura do texto, voltávamos para verificarmos se as hipóteses levantadas, de fato, condiziam com o assunto trato no texto.

As aulas de maior participação foram a terceira que levamos o conto "Negrinha" e a quarta aula, com o conto "Sobressalto". 0 conto Negrinha causou impacto devido ao sofrimento da órfã. Inicialmente, quando mostramos a capa do livro e pedimos para que eles dissessem quais os sentidos contidos na palavra negrinha, muitas coisas foram ditas, muitos contaram já ter sofrido preconceito por serem negros e chegaram a dizer que a palavra negrinha vem carregada de preconceito quando dita com certos gestos, expressões faciais, que eles sabem quando estão falando de forma preconceituosa porque a palavra vem acompanhada por algumas expressões "estranhas".

Observando os elementos relacionados ao conto apresentado, descobriram facilmente que Negrinha iria narrar uma história sobre uma menina negra, que sofria maus-tratos. Quando chegamos à leitura do conto muitos se emocionaram ao ver o sofrimento de $\mathrm{Ne}$ grinha e conseguiam perceber facilmente as ironias presentes no texto.

Após as cinco aulas, a atividade final de Santos buscou analisar se houve evolução na compreensão leitora, chegando aos seguintes dados: 
Quadro 4 - Análise comparativa dos dados

\begin{tabular}{|c|c|c|}
\hline Habilidades exigidas em cada questão: & \multicolumn{2}{|c|}{ ACERTOS: } \\
\hline \multirow{2}{*}{$\begin{array}{l}\text { Mobilização dos Conhecimentos Textuais: } \\
\text { Identificação do gênero/ Estrutura / Elementos }\end{array}$} & $\begin{array}{l}\text { Atividade } \\
\text { Diagnóstica }\end{array}$ & $\begin{array}{l}\text { Atividade } \\
\text { final }\end{array}$ \\
\hline & $\begin{array}{l}\text { Conto: } \\
\text { A aranha }\end{array}$ & $\begin{array}{c}\text { Conto: } \\
\text { Felicidade } \\
\text { Clandestina }\end{array}$ \\
\hline Identifica o gênero em estudo - Questão 1 & 04 & 09 \\
\hline Reconhece a estrutura do gênero - Questão 2 & 00 & 10 \\
\hline Aponta característica do gênero - Questão 3 & 05 & 06 \\
\hline Identifica os elementos que o compõem - Questão 4 & 02 & 10 \\
\hline \multicolumn{3}{|c|}{ Mobilização dos Conhecimentos Linguísticos: } \\
\hline \multicolumn{3}{|c|}{ Léxicos e Semânticos / Morfológicos e Sintáticos } \\
\hline $\begin{array}{l}\text { Busca o significado da palavra desconhecida para compreender o } \\
\text { texto - Questão } 5\end{array}$ & 00 & 10 \\
\hline $\begin{array}{l}\text { Organiza as palavras de acordo a classe gramatical que pertencem } \\
\text { - Questão } 6\end{array}$ & 00 & 10 \\
\hline Descobre o sentido da palavra a partir do contexto -7 & 05 & 08 \\
\hline \multicolumn{3}{|c|}{$\begin{array}{l}\text { Mobilização dos Conhecimentos enciclopédicos: } \\
\text { Conhecimentos de mundo }\end{array}$} \\
\hline $\begin{array}{l}\text { Mobiliza os conhecimentos de mundo específicos relacionados às } \\
\text { vivências pessoais (em termos culturais) - Questão } 8\end{array}$ & 01 & 08 \\
\hline $\begin{array}{l}\text { Aciona os conhecimentos de mundo mediante vivências pessoais } \\
\text { (em termos técnicos) - Questão } 9\end{array}$ & 04 & 10 \\
\hline $\begin{array}{l}\text { Ativa os conhecimentos gerais de mundo relacionados ao senso } \\
\text { comum - Questão } 10\end{array}$ & 01 & 07 \\
\hline
\end{tabular}

Fonte: Santos (2015, p. 59-60). 
Como podemos observar, houve um avanço significativo na compreensão leitora dos alunos. Além do avanço, Santos (2015, p. 62-63) comenta a mudança de postura dos alunos:

Verificamos durante a aplicação certo contentamento nos alunos em responderem às questões, o que não acontecia antes. Todos responderam tranquilamente, comentaram o quanto gostaram do texto, e a impressão que ficou foi que, de alguma forma, aquela atividade não tinha sido algo que eles iriam fazer por obrigação, mas estavam sentindo prazer em fazê-la. Comportamento diferente daquele que tiveram nas primeiras atividades, quando ler um texto, para muitos deles, parecia ser um peso, algo muito chato e cansativo. Essa atitude acabava contagiando, muitas vezes, o restante da turma, de modo que era preciso muito esforço para conseguir participação efetiva do grupo.

Quando um professor se disponibiliza a planejar suas aulas pensando de fato nos seus alunos, verificando suas dificuldades, buscando textos interessantes, discutindo, ouvindo, tornando as atividades prazerosas, reflexivas, significativas, transformando o ambiente em um local agradável, amoroso, sensível, seus alunos abraçarão o conhecimento, se tornarão disponíveis para aprender.

Falamos sobre oralidade, sobre leitura, falaremos agora sobre uma experiência com a escrita.

\section{Escrita e reescrita: etapas de um processo}

Rosemary da Silva Lima Oliveira, defendeu sua dissertação $A$ reescrita no processo de construção textual (2016), que se originou da sua angústia com o fato de os alunos não compreenderem o que é reescrever um texto, e, por isso, propôs elaborar uma sequência didática que auxiliasse o aluno nesta atividade:
Dessa forma, apresentamos nessa dissertação uma proposta de intervenção pedagógica, que fora aplicada em uma turma de $\mathbf{8}^{\mathrm{o}}$ ano de uma escola pública estadual situada no município de Santo Antônio de Jesus, na Bahia e pretendeu promover o desenvolvimento da competência escritora dos alunos, a partir das etapas de revisão e reescrita de textos de tipologia narrativa do gênero discursivo crônica. Tal proposta foi dividida em módulos baseados numa sequência didática e objetivou de maneira específica oportunizar ao aluno: compreender a estrutura e as características do gênero discursivo crônica; produzir um texto narrativo coerente; revisar seu texto, mediante intervenções pedagógicas; e reescrever seu próprio texto, buscando alcançar a qualidade da escrita. (OLIVEIRA, 2016, p.14).

Para o desenvolvimento da sua sequência didática, Oliveira (2016) optou trabalhar com a crônica, por considerar ser um gênero de grande circulação, que trata de temas do dia a dia e está presente nos livros didáticos.

Ao tratar da reescrita, Oliveira (2016, p. 26) diz:

Segundo Irandé Antunes (2003), na escola, a prática de produção escrita acontece num curto limite de tempo, no improviso e sem objetivos. Normalmente, há um planejamento apressado, e logo parte-se para a etapa da escrita, desconsiderando as outras etapas, o que favorece a elaboração de textos sem qualidade. Pelo fato da revisão e reescrita não serem uma prática constante, o aluno se preocupa apenas em escrever uma única versão daquilo que o professor quer ler e assim garantir sua nota. Desse modo, o aluno não tem oportunidade de realizar todas as etapas da escrita e não vê vantagem em planejar ou retomar o próprio texto, que, de certa forma, é visto como um produto já pronto e finalizado.

Oliveira (2015, p. 26) defende que [...] uma das possibilidades que o professor do ensino fundamental tem de fortalecer a 
proficiência do aluno no domínio da escrita é o planejamento de aulas que o estimulem a refletir sobre sua produção, percebendo os problemas e notando que o texto está aberto a mudanças e pode ser melhorado a cada nova reescrita.

E para isso, diz:

Nessa perspectiva, as práticas de ensino devem favorecer não apenas o desenvolvimento da produção textual, mas mostrar para o aluno que a escrita é um trabalho consciente, pensado e repensado. Levando-o a entender que para alcançar uma produção de maior qualidade, precisa seguir e respeitar as etapas de: planejar, escrever, revisar e reescrever, pois cada uma cumpre uma importante função no processo da escrita. (OLIVEIRA, 2016, p. 27).

A aplicação da sequência didática foi em uma escola estadual localizada em Santo Antonio de Jesus, no interior da Bahia, na qual Oliveira trabalha. Oliveira realizou uma atividade diagnóstica para verificar os conhecimentos sobre reescrita dos alunos e elaborar, então, a sequência didática. Os alunos cursavam o 7ํ․ ano quando realizaram a atividade diagnóstica. A sequência foi aplicada quando os alunos já estavam cursando o $8^{\circ}$. ano.

Na atividade diagnóstica, Oliveira (2016, p. 35) buscou

[...] inicialmente identificar com que frequência os alunos escrevem na sala de aula, como veem a reescrita e como praticam a reescrita a partir da proposta da escrita de uma crônica sobre algo relacionado ao cotidiano escolar, em uma versão preliminar (um rascunho) e uma versão final.

Para isso, solicitou que os alunos respondessem as seguintes questões (OLIVEIRA, 2016, p. 35):

1) Com que frequência você escreve textos na escola? E para quais atividades?

2) Você revisa seus textos antes de entregar ao professor? Se sim, o que você costuma observar na revisão?

3) Quando o(a) professor (a) devolve seu texto corrigido, você analisa o que foi corrigido? Por quê?

4) Qual a diferença entre revisar e reescrever um texto?

5) $\mathrm{Na}$ escola, você tem atividades de reescrita? Como são?

6) Você costuma reescrever seu texto? Se sim, o que você faz ao reescrevê-lo?

7) 0 que você acha da atividade de reescrita de um texto?

A análise geral de Oliveira das respostas ao questionário indicou a necessidade de um trabalho sistemático com escrita e reescrita de forma a levar os alunos a compreenderem o que é reescrever um texto e a importância desta atividade para se alcançar a excelência na produção textual. Apenas como ilustração das respostas, trazemos o quadro de Oliveira para as respostas à questão 4 e 7.

Quadro 5: Resposta à questão 4.

\begin{tabular}{|c|l|c|l|}
\hline ALUNOS & $\begin{array}{l}\text { 4) Qual a diferença entre revisar e } \\
\text { reescrever um texto? }\end{array}$ & ALUNOS & $\begin{array}{l}\text { 4) Qual a diferença entre revisar e } \\
\text { reescrever um texto? }\end{array}$ \\
\hline A1 & $\begin{array}{l}\text { Revisar: é só estudar. } \\
\text { Reescrever: escrever tudo de novo. }\end{array}$ & A16 & $\begin{array}{l}\text { Revisar: é fazer e responder } \\
\text { Reescrever: recopiar o que já está es- } \\
\text { crito. }\end{array}$ \\
\hline
\end{tabular}




\begin{tabular}{|c|c|c|c|}
\hline A2 & $\begin{array}{l}\text { Revisar: é corrigir o erro. } \\
\text { Reescrever: recopiar sem corrigir. }\end{array}$ & A17 & $\begin{array}{l}\text { Revisar: é verificar se está certo. } \\
\text { Reescrever: é copiar o texto e fazer } \\
\text { resumo da atividade. }\end{array}$ \\
\hline A3 & $\begin{array}{l}\text { Revisar: é corrigir o errado. } \\
\text { Reescrever: é copiar o mesmo texto. }\end{array}$ & A18 & $\begin{array}{l}\text { Revisar: é "olhar" o texto inteiro. } \\
\text { Reescrever: escrever de novo. }\end{array}$ \\
\hline A4 & $\begin{array}{l}\text { Revisar: verificar se está tudo certo. } \\
\text { Reescrever: escrever a mesma frase, } \\
\text { corretamente. }\end{array}$ & A19 & $\begin{array}{l}\text { Revisar: é ler o texto. } \\
\text { Reescrever: é escrever o mesmo tex- } \\
\text { to. }\end{array}$ \\
\hline A5 & $\begin{array}{l}\text { Revisar: verificar se tem algo errado. } \\
\text { Reescrever: refazer o texto. }\end{array}$ & A20 & $\begin{array}{l}\text { Revisar: é corrigir. } \\
\text { Reescrever: passar a limpo. }\end{array}$ \\
\hline A6 & $\begin{array}{l}\text { Revisar: verificar se não falta nada. } \\
\text { Reescrever: repetir o texto que já foi } \\
\text { escrito. }\end{array}$ & A21 & $\begin{array}{l}\text { Revisar: verificar os erros. } \\
\text { Reescrever: corrigir os erros. }\end{array}$ \\
\hline A7 & $\begin{array}{l}\text { Revisar: fazer pela "nossa cabeça" } \\
\text { Reescrever: só escreve. }\end{array}$ & A22 & $\begin{array}{l}\text { Revisar: é encontrar os erros. } \\
\text { Reescrever: é passar a limpo. }\end{array}$ \\
\hline A8 & $\begin{array}{l}\text { Revisar: é verificar os erros. } \\
\text { Reescrever: é escrever a mesma coisa. }\end{array}$ & A23 & $\begin{array}{l}\text { Revisar: ver se tem algo errado. } \\
\text { Reescrever: é corrigir aquilo que } \\
\text { errou. }\end{array}$ \\
\hline A9 & $\begin{array}{l}\text { Revisar: é verificar o erro. } \\
\text { Reescrever: é passar a limpo. }\end{array}$ & A24 & $\begin{array}{l}\text { Revisar: é ler o texto. } \\
\text { Reescrever: é escrever um texto. }\end{array}$ \\
\hline A10 & $\begin{array}{l}\text { Revisar: "olhar o texto" } \\
\text { Reescrever: é reescrever o texto antes } \\
\text { de entregar. }\end{array}$ & A25 & $\begin{array}{l}\text { Revisar: verificar se há erros. } \\
\text { Reescrever: é escrever o texto nova- } \\
\text { mente. }\end{array}$ \\
\hline A11 & $\begin{array}{l}\text { Revisar: verificar os erros. } \\
\text { Reescrever: reescrever o texto. }\end{array}$ & A26 & $\begin{array}{l}\text { Revisar: é reler e gravar. } \\
\text { Reescrever: é passar a limpo. }\end{array}$ \\
\hline A12 & $\begin{array}{l}\text { Revisar: analisar os erros. } \\
\text { Reescrever: escrever tudo de novo, } \\
\text { passar a limpo. }\end{array}$ & $\mathbf{A} 27$ & $\begin{array}{l}\text { Revisar: verificar o que foi feito. } \\
\text { Reescrever: corrigir o erro e passar } \\
\text { a limpo. }\end{array}$ \\
\hline A13 & $\begin{array}{l}\text { Revisar: verificar os erros. } \\
\text { Reescrever: escrever o texto mais } \\
\text { uma vez. }\end{array}$ & A28 & $\begin{array}{l}\text { Revisar: é verificar os erros. } \\
\text { Reescrever: é escrever novamente e } \\
\text { passar a limpo. }\end{array}$ \\
\hline A14 & $\begin{array}{l}\text { Revisar: é uma revisão. } \\
\text { Reescrever: é escrever. }\end{array}$ & A29 & $\begin{array}{l}\text { Revisar: é passar a limpo e resumir. } \\
\text { Reescrever: é corrigir os erros e es- } \\
\text { crever novamente. }\end{array}$ \\
\hline A15 & $\begin{array}{l}\text { Revisar: verificar acertos e erros. } \\
\text { Reescrever: refazer o texto. }\end{array}$ & A30 & $\begin{array}{l}\text { Revisar: analisar aquilo que errou. } \\
\text { Reescrever: é escrever a mesma coi- } \\
\text { sa. }\end{array}$ \\
\hline
\end{tabular}

Fonte: Oliveira (2016, p. 39). 
Para Oliveira (2016, p. 39),

Os alunos demonstraram que compreendem a etapa da revisão como uma atividade de verificação de erros gramaticais. Enquanto que a reescrita é considerada por quase todos como uma atividade de corrigir esses erros gramaticais e "passar o texto a limpo", a qual consiste na preocupação somente com o nível superfi- cial do texto: aspecto estético e correções localizadas de normas ortográficas. Ação que desconsidera os problemas que interferem na construção de sentido da produção textual. Apenas os alunos A5 e A15 revelam que essa etapa serve para melhorar o texto e refazer o texto, alinhando-se assim à abordagem de reescrita que adotamos nesse trabalho.

Quadro 6: Respostas à questão 7.

\begin{tabular}{|c|c|c|c|}
\hline ALUNOS & $\begin{array}{l}\text { 7) } 0 \text { que você acha da atividade de } \\
\text { reescrita de um texto? }\end{array}$ & ALUNOS & $\begin{array}{l}\text { 7) } 0 \text { que você acha da atividade de } \\
\text { reescrita de um texto? }\end{array}$ \\
\hline A1 & Considera ruim e muito cansativa. & A16 & $\begin{array}{l}\text { Às vezes considera uma atividade boa, } \\
\text { outras vezes acha ruim. }\end{array}$ \\
\hline A2 & $\begin{array}{l}\text { Considera uma atividade muito cansati- } \\
\text { va. }\end{array}$ & A17 & $\begin{array}{l}\text { Não gosta, mas acha uma atividade im- } \\
\text { portante. }\end{array}$ \\
\hline A3 & $\begin{array}{l}\text { Muito bem. Considera uma atividade } \\
\text { para melhorar o texto. }\end{array}$ & A18 & Reescreve o texto. \\
\hline A4 & Considera muito legal. & A19 & Acha desnecessária. \\
\hline A5 & $\begin{array}{l}\text { Uma atividade que pode melhorar o tex- } \\
\text { to. }\end{array}$ & A20 & Considera legal e gosta muito. \\
\hline A6 & $\begin{array}{l}\text { Considera uma atividade que serve para } \\
\text { aprender a fazer texto. }\end{array}$ & A21 & $\begin{array}{l}\text { Considera bom, porque ajuda a mente } \\
\text { a "funcionar" melhor ajuda a aprender } \\
\text { com os erros. }\end{array}$ \\
\hline A7 & Considera muito chata. & A22 & $\begin{array}{l}\text { Considera uma atividade pouco impor- } \\
\text { tante. }\end{array}$ \\
\hline A8 & $\begin{array}{l}\text { Às vezes considera uma atividade inte- } \\
\text { ressante, outras vezes acha chata. }\end{array}$ & A23 & $\begin{array}{l}\text { Considera uma atividade legal, porque } \\
\text { aprende a escrever corretamente. }\end{array}$ \\
\hline A9 & Não gosta muito. & A24 & Não gosta. \\
\hline A10 & Considera legal e interessante. & A25 & É bom para aprender mais. \\
\hline A11 & Não gosta muito. & A26 & Não gosta da atividade. \\
\hline A12 & $\begin{array}{l}\text { Não gosta, mas considera uma atividade } \\
\text { importante. }\end{array}$ & A27 & $\begin{array}{l}\text { Considera uma atividade chata, mas im- } \\
\text { portante. }\end{array}$ \\
\hline A13 & $\begin{array}{l}\text { Atividade que permite verificar os acer- } \\
\text { tos e erros. }\end{array}$ & A28 & Considera uma atividade legal. \\
\hline A14 & Considera interessante. & A29 & $\begin{array}{l}\text { Considera uma atividade boa para cor- } \\
\text { rigir os erros. }\end{array}$ \\
\hline A15 & $\begin{array}{l}\text { Tem preguiça de reescrever texto, prin- } \\
\text { cipalmente se for extenso. }\end{array}$ & A30 & Às vezes considera muito chata. \\
\hline
\end{tabular}

Fonte: Oliveira (2016, p. 41).

Para Oliveira (2016, p. 41),

Nessa questão, 08 alunos evidenciaram que consideram a atividade da reescrita "cha- ta”, ruim, pouco interessante, desnecessária e cansativa. Outros 05 afirmaram que "não gostam" da atividade; 07 alunos consideram 
uma atividade que serve para aprender a "fazer" texto, para melhorar o texto ou para corrigir os erros; 06 alunos afirmaram que a reescrita é uma atividade importante, mas não apresentaram argumentos plausíveis que sustentem essa afirmação, pois se utilizam de palavras imprecisas e vagas como: legal, interessante e boa para caracterizar a reescrita. Apenas 01 aluno afirmou ter preguiça para reescrever seus textos e outro respondeu somente que reescreve, sem emitir opinião sobre a atividade.

As informações registradas nessa sétima questão são esclarecedoras de algumas das dificuldades dos alunos com a produção escrita e da resistência em considerar as etapas de produção. Mais uma vez, suspeitamos que a revisão e a reescrita não estejam sendo trabalhadas na escola. Conjecturamos que o texto do aluno é corrigido superficialmente e devolvido, encerrando-se aí o trabalho de produção textual.

Além deste questionário, a atividade diagnóstica seguiu em outra aula com a leitura de uma crônica, buscando identificar o gênero e a solicitação da escrita de uma crônica sobre algo do cotidiano da escola. Para esta escrita, Oliveira entregou uma folha para rascunho e outra para a versão final, mas sem estabelecer necessariamente uma questão de revisão, justamente para verificar o que fariam, se praticariam o ato da reescrita.

Oliveira (2016, p. 44) diz:

Analisando a folha de rascunho, destinada à primeira versão do texto, constatamos o seguinte [..]: 12 alunos utilizaram a folha de rascunho, 05 deixaram a folha em branco e 08 usaram a folha apenas para desenhar. As formas de utilização da folha de rascunho podem ser vistas no [...]. Desses 24 alunos que produziram o texto, 16 haviam afirmado no questionário sobre a reescrita que reescrevem sempre seus textos. Sendo assim, levantamos algumas hipóteses para explicar por que mais da metade dos alunos ignoram ou relegam as etapas da revisão e da reescrita. Diversos podem ser os motivos: falta de interesse, preguiça, falta de incentivo, falta de orientação, falta de hábito, desconhecimento da utilidade dessa folha; falta de tempo ou pressa. Seja qual for o motivo, acreditamos que a revisão e reescrita não têm sido trabalhadas de forma que os alunos compreendam a sua importância no processo de escrita de um texto.

Diante do diagnóstico, Oliveira (2016, p. 48-49) constatou que

[...] os alunos ainda não usam a reescrita como uma atividade que faz parte do processo de produção textual com propriedade de forma a levar a um desenvolvimento da escrita. Também verificamos que eles não dominam o gênero discursivo crônica como seria esperado no $8^{\circ}$ ano do ensino fundamental.

Partindo das informações encontradas na aplicação do diagnóstico, Oliveira elaborou uma sequência didática em que trabalhou o que é a crônica, sua composição e questões de língua, as etapas da produção escrita, a escrita de uma crônica e, finalmente, a sua reescrita, compreendendo a revisão, a reescrita e a divulgação dos textos no blog da escola. Oliveira usou como estratégia de correção das primeiras versões dos alunos comentários em forma de bilhetes, que é uma

[...] espécie de intervenção apresentada por Ruiz (2013): a correção textual-interativa. Essa correção apresenta uma maneira diferenciada de abordagem das inadequações dos textos. Ela traz comentários - em forma de bilhete, mais extensos do que os que se fazem na margem-, escritos logo abaixo do texto do aluno, mostrando discordâncias locais e sugerem mudanças no texto a níveis micro e macroestrutural, atentando para os aspectos globais. (OLIVEIRA, 2016, p. 64).

Para Oliveira (op. cit. p. 65),

Tais bilhetes se constituem como verdadeiros "[...] aliados ao espaço para a reescrita 
abrem caminho para uma reflexão sobre o próprio texto e para a aprendizagem de práticas de escrita." (NASCIMENTO, 2013, p.77). Em outras palavras, eles proporcionam um diálogo entre produtor (aluno) e coprodutor (professor).

Portanto, digitamos um bilhete orientador [...] para cada texto, observando obviamente as necessidades de intervenções de cada produção. Anexamos esse bilhete ao texto do aluno. Em todos os bilhetes tecemos elogios ao texto, estimulando o aluno às novas possibilidades de escrita e à prática da reescrita e nos colocamos à disposição para orientar.
Ao final da sequência didática, Oliveira (2016, p. 100-101) conclui que

Terminadas as análises, verificamos que as dificuldades dos alunos foram comuns e que durante a reescrita eles se mostraram interessados nas orientações do bilhete e as sugestões pedagógicas. Buscaram modificar o texto como uma melhor forma de dizer aquilo que pretendiam.

0 resultado de todo o desenvolvimento da sequência didática proposta por Oliveira pode ser verificado na comparação dos quadros abaixo com as análises de 16 alunos:

Quadro 7- Quadro avaliativo: critérios atendidos na primeira versão.

\begin{tabular}{|c|c|c|c|c|c|}
\hline \multicolumn{6}{|c|}{ CRITÉRIOS ATENDIDOS - PRIMEIRA VERSÃO } \\
\hline ALUNO & $\begin{array}{l}0 \text { título do } \\
\text { texto des- } \\
\text { perta para a } \\
\text { leitura. }\end{array}$ & $\begin{array}{l}\text { O texto narra um } \\
\text { pequeno aconte- } \\
\text { cimento da vida } \\
\text { diária. }\end{array}$ & $\begin{array}{l}\text { A narrativa } \\
\text { está organiza- } \\
\text { da em primei- } \\
\text { ra ou terceira } \\
\text { pessoa. }\end{array}$ & $\begin{array}{l}\text { Estão presentes no } \\
\text { texto todas as carac- } \\
\text { terísticas da narrativa } \\
\text { (personagem, cenário, } \\
\text { tempo, conflito e des- } \\
\text { fecho). }\end{array}$ & $\begin{array}{c}\text { O enredo do texto } \\
\text { está bem desen- } \\
\text { volvido, coerente. } \\
\text { Há uma unidade } \\
\text { de ação. }\end{array}$ \\
\hline A1 & & $\mathrm{X}$ & $\mathrm{X}$ & & $\mathrm{X}$ \\
\hline \multicolumn{6}{|l|}{$\mathrm{A} 2$} \\
\hline \multicolumn{6}{|l|}{ A3 } \\
\hline A4 & Sem título. & $\mathrm{X}$ & $\mathrm{X}$ & & \\
\hline A5 & $\mathrm{X}$ & $\mathrm{X}$ & $\mathrm{x}$ & $\mathrm{X}$ & \\
\hline \multicolumn{6}{|l|}{ A6 } \\
\hline A7 & & $\mathrm{X}$ & $\mathrm{X}$ & $\mathrm{X}$ & $\mathrm{X}$ \\
\hline A8 & $\mathrm{x}$ & $\mathrm{X}$ & $\mathrm{X}$ & $\mathrm{X}$ & $\mathrm{X}$ \\
\hline A9 & Sem título. & & $\mathrm{X}$ & $\mathrm{X}$ & $\mathrm{X}$ \\
\hline A10 & & $\mathrm{X}$ & $\mathrm{X}$ & $\mathrm{X}$ & $\mathrm{X}$ \\
\hline \multicolumn{6}{|l|}{ A11 } \\
\hline A12 & & $X$ & $X$ & $X$ & $X$ \\
\hline A13 & $X$ & $X$ & $X$ & $X$ & $X$ \\
\hline A14 & $X$ & $X$ & $\mathrm{X}$ & $X$ & $\mathrm{X}$ \\
\hline A15 & & $X$ & $X$ & & \\
\hline A16 & Sem título. & $\mathrm{X}$ & & & \\
\hline
\end{tabular}




\begin{tabular}{|c|c|c|c|c|c|}
\hline ALUNO & $\begin{array}{l}0 \text { texto utiliza } \\
\text { uma lingua- } \\
\text { gem informal. }\end{array}$ & $\begin{array}{l}0 \text { autor apresenta } \\
\text { seu posiciona- } \\
\text { mento sobre o fato } \\
\text { narrado. }\end{array}$ & $\begin{array}{l}\text { O texto des- } \\
\text { perta humor, } \\
\text { crítica ou } \\
\text { reflexão }\end{array}$ & $\begin{array}{c}\text { O texto emprega re- } \\
\text { cursos linguísticos } \\
\text { (vocabulário e figuras } \\
\text { de linguagem) numa } \\
\text { dimensão literária/ } \\
\text { lírica. } \\
\end{array}$ & $\begin{array}{l}\text { O texto apresenta } \\
\text { inadequações } \\
\text { gramaticais que } \\
\text { comprometem seu } \\
\text { entendimento. }\end{array}$ \\
\hline $\mathrm{A} 1$ & $\mathrm{X}$ & $\mathrm{X}$ & $\mathrm{X}$ & & \\
\hline A2 & $\mathrm{X}$ & & & & $\mathrm{X}$ \\
\hline A3 & $\mathrm{X}$ & & & & $\mathrm{X}$ \\
\hline $\mathrm{A} 4$ & $\mathrm{X}$ & $\mathrm{X}$ & & & $\mathrm{X}$ \\
\hline A5 & $\mathrm{X}$ & & & & $\mathrm{X}$ \\
\hline A6 & $\mathrm{X}$ & $\mathrm{X}$ & $\mathrm{X}$ & & \\
\hline A7 & $\mathrm{X}$ & $\mathrm{X}$ & & & \\
\hline A8 & $\mathrm{X}$ & $\mathrm{X}$ & & & \\
\hline A9 & $\mathrm{X}$ & & & & \\
\hline A10 & $\mathrm{X}$ & $\mathrm{X}$ & $\mathrm{X}$ & & \\
\hline A11 & $X$ & & & & $X$ \\
\hline A12 & $\mathrm{X}$ & $\mathrm{X}$ & $\mathrm{X}$ & & \\
\hline A13 & $\mathrm{X}$ & $\mathrm{X}$ & $\mathrm{X}$ & & \\
\hline A14 & $\mathrm{X}$ & $\mathrm{X}$ & $\mathrm{X}$ & & \\
\hline A15 & $\mathrm{X}$ & & & & $\mathrm{X}$ \\
\hline A16 & $\mathrm{X}$ & $\mathrm{X}$ & & & \\
\hline \multicolumn{6}{|c|}{$\begin{array}{l}\text { LEGENDA: } \\
x\end{array}$} \\
\hline \multicolumn{3}{|c|}{ Alcançou o critério. } & \multicolumn{2}{|c|}{ Não alcançou o critério. } & \\
\hline
\end{tabular}

Fonte: Oliveira (2016, p. 101)

Quadro 8: Quadro avaliativo: critérios atendidos na segunda versão.

\begin{tabular}{|c|c|c|c|c|c|}
\hline \multicolumn{6}{|c|}{ CRITÉRIOS ATENDIDOS — SEGUNDA VERSÃO } \\
\hline ALUNO & $\begin{array}{l}0 \text { título do } \\
\text { texto des- } \\
\text { perta para a } \\
\text { leitura. }\end{array}$ & $\begin{array}{l}0 \text { texto narra um } \\
\text { pequeno aconte- } \\
\text { cimento da vida } \\
\text { diária. }\end{array}$ & $\begin{array}{l}\text { A narrativa está } \\
\text { organizada em } \\
\text { primeira ou ter- } \\
\text { ceira pessoa. }\end{array}$ & $\begin{array}{l}\text { Estão presentes no tex- } \\
\text { to as características da } \\
\text { narrativa (personagem, } \\
\text { cenário, tempo, conflito } \\
\text { e desfecho). }\end{array}$ & $\begin{array}{l}\text { O enredo do texto } \\
\text { está bem desenvol- } \\
\text { vido, coerente. Há } \\
\text { uma unidade de } \\
\text { ação. }\end{array}$ \\
\hline A1 & $\mathrm{X}$ & $\mathrm{X}$ & $\mathrm{X}$ & $x$ & $\mathrm{X}$ \\
\hline \multicolumn{6}{|l|}{ A2 } \\
\hline A3 & & $\mathrm{X}$ & $X$ & $\mathrm{X}$ & $\mathrm{X}$ \\
\hline A4 & & $\mathrm{X}$ & $X$ & $\mathrm{X}$ & $\mathrm{X}$ \\
\hline A5 & $\mathrm{X}$ & $\mathrm{X}$ & $\mathrm{X}$ & $x$ & $x$ \\
\hline A6 & & & & & \\
\hline
\end{tabular}




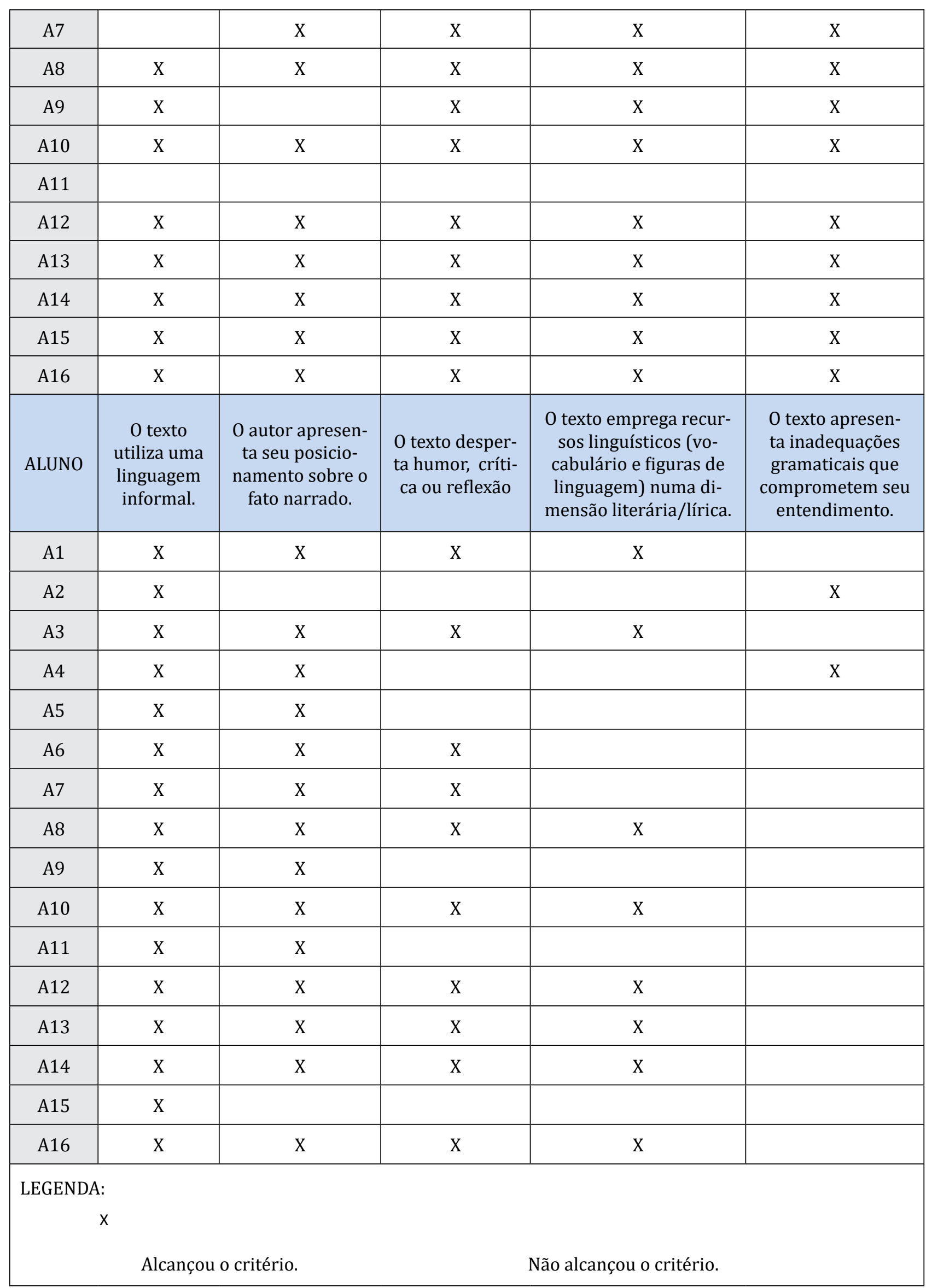

Fonte: Oliveira (2016, p.101). 
Como podemos verificar na comparação entre a primeira e a segunda versão,

[...] a reescrita mediada pelo bilhete orientador e pelos encaminhamentos pedagógicos individualizados se constituiu como suporte para que os dezesseis alunos realizassem modificações qualitativas em seus textos. (OLIVEIRA, 2016, p. 103).

Oliveira ainda faz algumas considerações finais que consideramos importantes sobre os resultados da sua proposta para reflexão:

Podemos refletir ainda sobre outros resultados que consideramos valiosos. Esse trabalho foi construído com muita dedicação e empenho, num ambiente de confiança no qual conseguimos envolver os alunos, despertando-lhes o comprometimento para a prática da escrita. Dessa forma, notamos uma evolução na atitude deles em cada etapa da proposta. A atividade diagnóstica nos revelou que muitos alunos por falta de prática e estímulo escreviam o texto em uma única versão, sem planejamento, acreditando já ter encerrado o trabalho da produção. Além disso, se recusavam a refletir sobre o texto e resistiam à etapa da reescrita. Porém, durante o desenvolvimento das atividades dessa proposta, os alunos se motivaram e mobilizaram esforços para elaborar um texto, vencendo o sentimento de incapacidade. Eles aprenderam a serem leitores dos seus próprios textos e se demonstraram satisfação em realizar as etapas do processo da escrita. Ou seja, escolheram um tema para o texto, planejaram a escrita, escreveram a primeira versão, revisaram, mesmo com pouca experiência em verificar seus erros, aceitaram as sugestões e orientações pedagógicas e reescreveram o texto, buscando o aprimoramento. E compreenderam que para elaborar uma produção com qualidade é preciso considerar/seguir cada uma das etapas do processo da escrita, já que o texto não é um produto finito de dimensões acabadas, mas uma produção que pode ser modificada quantas vezes se fizer necessário para que se alcance os resultados almejados. Diante disso, não podemos negar a importância da nossa proposta de intervenção tanto para os alunos quanto para a nossa formação docente. Já que esse trabalho nos levou a perceber que é possível romper com velhas práticas metodológicas e planejar atividades de produção de texto, que tenham como unidade básica do ensino o texto realizado em gênero discursivo, construído em situações reais de comunicação, possibilitando condições mais efetivas de ensino e aprendizagem de língua, ultrapassando o ensino superficial de estabelecimento de conceitos e normas ligados aos fatos gramaticais. (OLIVEIRA, 2016, p. 105-106).

Podemos verificar que a partir de um planejamento comprometido do professor, da sua avaliação diagnóstica, o desenvolvimento de atividades significativas se torna uma forma eficiente de desenvolver as habilidades linguísticas do aluno, sendo o caso aqui do desenvolvimento da escrita por meio da compreensão das etapas que envolvem o ato de escrever, sendo o foco nesta proposta de Oliveira a etapa da reescrita.

Propostas como as de Oliveira, de Santos e de Viana são frutos de uma nova concepção de mestrado, o mestrado profissional, que alia as reflexões teóricas à prática docente.

Para finalizar, retomaremos a relação cognição - aprendizagem, buscando mostrar como as sequências didáticas aqui apresentadas vão ao encontro dos fatores envolvidos na aprendizagem.

\section{Considerações finais}

É importante dizer que PROFLETRAS, além de inovar ao ter como objetivo aliar a teoria à prática de sala de aula por meio da elaboração de propostas a serem aplicadas na própria escola do orientando, também inova ao ser um dos poucos que traz a disciplina "Aspectos sociocognitvos e metacognitivos da leitura e da escrita", que tem 
como foco o estudo dos aspectos dos processos sociocognitivos e metacognitivos relacionados à aquisição da linguagem e ao aprendizado e desenvolvimento da leitura e da escrita, refletindo sobre a articulação entre as abordagens cognitivas da leitura e da escrita e as pesquisas sobre letramento, de forma a levar os alunos à elaboração de didáticas para o ensino de Língua Portuguesa com base na construção sociocognitiva e metacognitiva do significado relacionada ao trato com textos orais e escritos. (BORBA, 2019, p. 174-175).

\section{Conforme Borba (2019, p. 175),}

Tratar de estudos sociocognitivos e metacognitivos implica reconhecer o ser humano como um ser cognitivo, biológico, cultural, social, histórico. E sendo cognitivo e biológico, sua construção enquanto ser cultural, social e histórico se dá na interação com o meio ambiente, que proporcionará as ex- periências que o constituirão, sendo fundamental levar em conta percepções e sentidos do aprendiz, que dependem tanto das estruturas biológicas, do corpo, da sua história registrada na memória, do seu conhecimento prévio, como das experiências que lhe serão proporcionadas. Assim, é fundamental conhecer como todo esse processo se dá em termos neurocientíficos, o que envolve ir do biológico ao social.

Assim, retomando o quadro sobre fatores envolvidos na aprendizagem, apresentados na seção 2, podemos dizer que nossas orientandas, ao elaborarem as suas sequências didáticas, consideraram o aporte teórico estudado na disciplina sobre os processos envolvidos na aprendizagem. Vejamos uma síntese dos fatores envolvidos na aprendizagem que pudemos perceber na elaboração e aplicação das sequências didáticas:

Quadro 9 - Fatores envolvidos na aprendizagem

\begin{tabular}{|c|c|c|c|c|c|}
\hline Ambientais & Interacionais & Biológicos & Cognitivos & Subjetivos & $\begin{array}{c}\text { Tempo de } \\
\text { experiência } \\
\text { prática }\end{array}$ \\
\hline $\begin{array}{l}\text { O ambiente } \\
\text { físico das es- } \\
\text { colas era ra- } \\
\text { zoável. } \\
\text { Os estímulos } \\
\text { oferecidos fo- } \\
\text { ram variados, } \\
\text { buscando cha- } \\
\text { mar a atenção } \\
\text { dos alunos por } \\
\text { meio de mate- } \\
\text { riais diversos, } \\
\text { sempre levan- } \\
\text { do em conta o } \\
\text { contexto geral } \\
\text { de possibilida- } \\
\text { des. }\end{array}$ & $\begin{array}{l}\text { As três professo- } \\
\text { ras consideraram } \\
\text { o contexto em } \\
\text { que estavam } \\
\text { envolvidas, } \\
\text { mostraram ter } \\
\text { uma relação in- } \\
\text { terpessoal boa } \\
\text { com os alunos, } \\
\text { demonstrando } \\
\text { afeto e respeito à } \\
\text { cultura deles. } \\
\text { A metodologia } \\
\text { adotada buscou } \\
\text { uma interação } \\
\text { com os alunos de } \\
\text { forma participa- } \\
\text { tiva e democrá- } \\
\text { tica }\end{array}$ & $\begin{array}{l}\text { A princípio, } \\
\text { as três profes- } \\
\text { soras tinham } \\
\text { alunos saudá- } \\
\text { veis. } \\
\text { Mesmo que, } \\
\text { eventualmen- } \\
\text { te cansados } \\
\text { pela distân- } \\
\text { cia, às vezes } \\
\text { percorridas } \\
\text { por alunos da } \\
\text { zona rural, as } \\
\text { professoras } \\
\text { conseguiram } \\
\text { que seus alu- } \\
\text { nos prestas- } \\
\text { sem atenção } \\
\text { às aulas. }\end{array}$ & $\begin{array}{l}\text { As três profes- } \\
\text { soras aplica- } \\
\text { ram atividades } \\
\text { diagnósticas de } \\
\text { forma a verificar } \\
\text { o conhecimen- } \\
\text { to prévio dos } \\
\text { alunos, de for- } \\
\text { ma a elaborar } \\
\text { atividades que } \\
\text { desenvolvessem } \\
\text { as habilidades } \\
\text { cognitivas e me- } \\
\text { tacognitivas. } \\
\text { A atenção foi } \\
\text { alcançada por } \\
\text { meio de ativida- } \\
\text { des que motiva- } \\
\text { vam os alunos. }\end{array}$ & $\begin{array}{l}\text { As três se- } \\
\text { quências } \\
\text { didáticas } \\
\text { apresentadas } \\
\text { buscaram } \\
\text { mostrar aos } \\
\text { alunos os } \\
\text { objetivos } \\
\text { de forma } \\
\text { clara, mo- } \\
\text { tivando-os, } \\
\text { buscando ir } \\
\text { ao encontro } \\
\text { de seus inte- } \\
\text { resses, sendo } \\
\text { relevantes e } \\
\text { considerando } \\
\text { a experiência } \\
\text { deles. }\end{array}$ & $\begin{array}{l}\text { Todas as três } \\
\text { sequências fo- } \\
\text { ram realizadas } \\
\text { em um tempo } \\
\text { suficiente para } \\
\text { o desenvol- } \\
\text { vimento das } \\
\text { habilidades } \\
\text { desejadas e } \\
\text { com práticas } \\
\text { variadas e } \\
\text { suficientes de } \\
\text { acordo com a } \\
\text { necessidade } \\
\text { verificada. }\end{array}$ \\
\hline
\end{tabular}

Fonte: Elaborado pela autora. 
Como podemos observar no quadro acima, a elaboração de sequências didáticas que leve em consideração aspectos relacionados à cognição favorece uma aprendizagem real. Todos os aspectos envolvidos na aprendizagem, quando observados, proporcionam o reforço das sinapses, favorecendo a aprendizagem.

A orientação de estudos e pesquisas em linguística aplicada, uma das nossas atividades na universidade, tem por objetivo estudar e pesquisar questões referentes às práticas de oralidade, leitura e escrita, levando em conta como o cérebro aprende, buscando subsídios na neurociência para uma maior compreensão do processo de ensino-aprendizagem a partir de uma visão da complexidade envolvida nesse processo, ou seja, da compreensão do ser humano enquanto um ser biológico, histórico, social, inserido em ambientes diversos e com experiências únicas. Logo, ao se pensar em cognição e ensino-aprendizagem, é preciso considerar todos os fatores que podem favorecer o reforço das sinapses, de forma que haja aprendizagem, e isso perpassa desde a relação entre os sujeitos, o ambiente físico, os recursos, as estratégias etc.

\section{Referências}

BORBA, V. C. M. Instrução e produção textual: um estudo com contos de assombração. Maceió: EDUFAL, 2013.

Cognição e ensino-aprendizagem: da teoria à prática. In: Gelne 40 anos [recurso eletrônico] : vivências teóricas e práticas nas pesquisas em linguística e literatura, volume 2 / organiza- ção Cleber Ataíde ... [et al.]. - 1. ed. - São Paulo : Pá de Palavra, 2018.

. Cognição e aprendizagem na sala de aula: toda criança é única. Letras em Revista (ISSN 2318-1788), Teresina, v. 10, n. 01, jan./jun. 2019.

BRASIL, Ministério da Educação. Base Nacional Comum Curricular (Terceira Versão). Ministério da Educação, Brasília, DF: MEC, 2017. Disponível em: http://basenacionalcomum.mec.gov. br/images/BNCC_publicacao.pdf . Acesso em: 29 nov. 2020.

Brasil, Secretaria de Educação Fundamental. Parâmetros Curriculares Nacionais: terceiro e quarto ciclos do ensino fundamental: língua portuguesa/Secretaria de Educação Fundamental. Brasília: MEC/SEF, 1998.

CHIELE, L. K. O modelo conexionista na interface da inteligência e do aprendizado da leitura. Letras de Hoje. V. 33, no. 2, p. 57-62. Porto Alegre: Edipucrs, 1998.

OLIVEIRA, R. da S. L. A reescrita no processo de construção textual. 2016. 151f. Dissertação (Mestrado Profissional em Letras) - Universidade do Estado da Bahia, Santo Antônio de Jesus, 2017.

VIANA, T. C. C. de S. Argumentação na oralidade: uma proposta de ensino a partir dos gêneros diálogo argumentativo e debate. 2017. 193f. Dissertação (Mestrado Profissional em Letras) Universidade do Estado da Bahia, Santo Antônio de Jesus, 2017.

SANTOS, E. R. dos. Conhecimento prévio e compreensão leitora: uma proposta pedagógica. 131f. Dissertação (Mestrado Profissional em Letras) - Universidade do Estado da Bahia, Santo Antônio de Jesus, 2013.

Recebido em: 15/04/2021 Aprovado em: 10/08/2021 